AMERICAN UNIVERSITY WORKING PAPER SERIES

POLITICS, NOT ECONOMICS, ULTIMATELY DRIVES INEQUALITY

Jon D. Wisman

Working Paper 2017-06
http://www.american.edu/cas/economics/research/upload/2017-06.pdf

JEL No.: D63, B00, Z18, N3

AMERICAN UNIVERSITY

4400 Massachusetts Ave., N.W.,

Washington, D.C. 20016-8029

\begin{abstract}
Over the past 40 years, inequality has exploded in the U.S. and significantly increased in virtually all nations. Why? The current debate typically identifies the causes as economic, due to some combination of technological change, globalization, inadequate education, demographics, and most recently, Piketty's claim that it is the rate of return on capital exceeding the growth rate. But to the extent true, these are proximate causes. They all take place within a political framework in which they could in principle be neutralized or reversed. Indeed, this mistake is itself political. It masks the true cause of inequality and presents it as if natural, due to the forces of progress, just as in pre-modern times it was the will of gods. By examining three broad distributional changes in modern times, this article demonstrates the dynamics by which inequality is a political phenomenon through and through. It places special emphasis on the role played by ideology - politics' most powerful instrument - in making inequality appear as necessary.
\end{abstract}


Working Paper April 2017

\title{
POLITICS, NOT ECONOMICS, ULTIMATELY DRIVES INEQUALITY
}

\author{
Jon D. Wisman ${ }^{1}$
}

"[T]here is no such thing as a purely economic problem that can be settled by purely economic logic; political interests and political prejudice are involved in every discussion of actual questions" (Joan Robinson 1981, 2-3).

Abstract: Over the past 40 years, inequality has exploded in the U.S. and significantly increased in virtually all nations. Why? The current debate typically identifies the causes as economic, due to some combination of technological change, globalization, inadequate education,

demographics, and most recently, Piketty's claim that it is the rate of return on capital exceeding the growth rate. But to the extent true, these are proximate causes. They all take place within a political framework in which they could in principle be neutralized or reversed. Indeed, this mistake is itself political. It masks the true cause of inequality and presents it as if natural, due to the forces of progress, just as in pre-modern times it was the will of gods. By examining three broad distributional changes in modern times, this article demonstrates the dynamics by which inequality is a political phenomenon through and through. It places special emphasis on the role played by ideology - politics' most powerful instrument - in making inequality appear as necessary.

JEL Classification Codes: D63, B00, Z18, N3.

Keywords: Political power; Distribution; Legitimation; Ideology.

Inequality has exploded in the U.S. and significantly increased in virtually all countries around the world since the 1970s. Why? The current explanations typically identify the causes as economic, due to some combination of technological change, globalization, inadequate education, or demographics. At times a few recognize a role for politics, but it seldom gets center stage.

The thesis of this article is that inequality is a political phenomenon through and through. Other forces such as the economic ones typically offered by economists are not without importance, but they are proximate causes. They all take place within a political framework in which what enables them to increase inequality could be altered, or their effects could be neutralized.

This mistake of focusing on proximate causes while ignoring underlying political forces is itself political. It masks the true cause of inequality and presents it as if it is natural or due to the forces of progress, just as in pre-modern times it was the will of gods. Thus, it is as it must be. Moreover, nothing is to be done lest the dynamics of economic growth be derailed.

\footnotetext{
${ }^{1}$ Professor of Economics at American University, Washington, D.C.
} 
This article makes two claims. The first is that the ultimate cause of inequality is political. The second claim is that ideology is the most important political tool. The strategy followed to support these claims is to examine the political dynamics underlying three broad trends in distribution since the nineteenth century.

This article unfolds as follows. The next section provides a brief summary of the discipline's contention that inequality is caused by economic forces. In the third section, Kuznets' famous "turning point" is explored to demonstrate the manner in which it was powered by political forces. The fourth section unfolds the critical role of ideology as the most important determinant of political power with a special focus on the role played by "economic science." The fifth section uses this understanding of ideology for grasping the four decades of declining inequality between the 1930's and 1970s and the subsequent four-decade explosion of inequality in the United States. Due to space constraints, analysis is restricted to the United States. ${ }^{2}$ The article concludes with a few reflections on the current state of the economics discipline and the prospects for lessened inequality.

\section{Identifying Economic Forces as the Causes of Inequality}

Inequality is hardly new. Extreme inequality has characterized almost all of human history since the dawn of civilization about 5,500 years ago. Powerful elites typically captured most, if not all of societies' economic surplus, leaving the overwhelming majority of humanity with bare subsistence, just enough to survive.

Hope that this historical pattern could be broken was born philosophically over two centuries ago with the Enlightenment. More recently, the belief that growing equality would characterize humanity's future came forth in a landmark article published over a half-century ago by economist Simon Kuznets (1955). Kuznets offered - in a conjecture he characterized as "perhaps 5 percent empirical information and 95 percent speculation, some of it possibly tainted by wishful thinking" $(1955,26)$-- that although inequality increases in the early stages of economic development, at some more advanced level, inequality begins decreasing - an inverted U curve. Kuznets' article unleashed the hope and expectation that in the end economic growth would deliver lessened inequality. His conjecture came to be seen as "conventional wisdom" (Lantican, Gladwin, and Seale 1996, 243), "some sort of 'iron law' of development" (Srinivasan 1977, 15), "one of the most enduring and remarkable arguments in the history of the social sciences... [such that] By the end of the 1970s, the inverted U-curve process was universally considered a general statement of the historical and universal relationship between income inequality and economic growth" (Moran 2005, 209; 218).

Kuznets, however, did not believe that the shift toward greater equality would be driven by purely economic forces. He held that political and social forces would be important, that political pressure for greater equality would come forth as the lower classes attained greater social and political organization such that redistributive government intervention would play a role. Nevertheless, he limited his analysis to mostly economic variables because "Space does not permit the discussion of demographic, political, and social considerations that could be brought to bear..." (1955, 17-18). Nevertheless, in closing his article, Kuznets wrote that "it is inevitable that we venture into fields beyond those recognized in recent decades as the province of economics proper.... Effective work in this field necessarily calls for a shift from market

\footnotetext{
${ }^{2}$ The U.S. story is noteworthy for its extremes. Thomas Piketty finds that the United States “... was less inegalitarian than Europe in 1900-1910, slightly more inegalitarian in 1950-1960, and much more inegalitarian in 2000-2010 (2014, 324).
} 
economics to political and social economy" $(1955,28)$.

Apparently, few paid attention to Kuznets' concluding reflection. Morphed into "iron law," Kuznets' conjecture suggested that rising inequality in developing countries need not be of much concern since it was merely part of the story of successful economic development. Some development economists even viewed rising inequality as growth enhancing in poorer countries (e.g., Moran 2005). Notably, as if anticipating such arguments, Kuznets wrote of the need to "avoid the fatally simple remedy of [using] the population as cannon-fodder in the fight for economic achievement" $(1995,25)$. But in spite of his entreaty, cannon-fodder they were to be.

As for the rich countries, because inequality was destined to decline, redistributive public policy measures might be viewed as less urgent or not even necessary. Inequality would "naturally" decline in due course with continued economic growth. Indeed, insofar as greater equality was viewed as being brought forth in rich countries by economic forces, nothing need be done. Ironically, Kuznets' conjecture came to serve as a powerful ideology legitimating political inaction.

Although from the 1980s on there were rising doubts about the empirical validity of the Kuznets' Curve, it nevertheless lived on. However, the explosion in inequality over the past several decades has clearly foiled the expectations Kuznets unleashed.

The tendency of economists to limit their analysis to economic forces in the determination of secular trends in distribution is evident in their explanations of Kuznets' inflection point defining the shift from growing inequality during early economic development to lessened inequality with subsequent more mature economic development. These explanations include Kuznets' (1955) own reflection that it was due to the switch from agriculture to industrialization; Peter Lindert's (1986) hypothesis that it was due to the declining importance of land income; Jeffrey Williamson's (2005) hypothesis that the wage share increased due to technological change; ${ }^{3}$ Jan Tinbergen's hypothesis that income distribution depended upon the relative expansion rates of skill-biased technological change and education (1974); and Phillip Aghion and Patrick Bolton's (1997) hypothesis that savings by the rich push down the interest rate, permitting the less well-off to borrow and invest, thereby catching up.

It must be noted that the primacy of politics is recognized by some economists, especially heterodox economists and those with a historical bent. For instance, Daron Acemoglu and James Robinson's treatise on Why Nations Fail is grounded in an understanding that "while economic institutions are critical for determining whether a country is poor or prosperous, it is politics and political institutions that determine what economic institutions a country has" (Acemoglu and Robinson 2012, 43). But generally, even when economists recognize a political dimension to inequality, they do so in a manner that continues to view economic forces as somehow or somewhat independent of the political world. Thus, Joseph Stiglitz claims that "A major theme of this book is that inequality is the result of political forces as much as of economic ones" $(2012,30)$. He appears not to recognize that the economic forces are embedded in the political, and thus can be overridden by the latter.

An especially curious example is Thomas Piketty who has done so much to bring attention to the degree and extent of contemporary inequality. He peppers his best-selling book,

\footnotetext{
${ }^{3}$ In an earlier article, he claimed that "market forces have been at the heart of twentieth-century egalitarian trends among the industrialized countries... [these changes] seem to have been driven by changes in factor rewards... thus setting the Kuznets Curve in motion, and contributing to turning points" $(1991,13,17)$.
} 
Capital in the Twenty-First Century, with statements that distribution is ultimately an issue of politics. For instance, early in the book, he writes "The history of the distribution of wealth has always been deeply political, and it cannot be reduced to purely economic mechanism"(2014, 20). Yet he bases most of his theoretical analysis and much of his historical analysis, as well as his prediction of greater future inequality, on the rate of return on capital exceeding the rate of economic growth $(r>g)$. He announces that this "fundamental inequality... sums up the overall logic of my conclusions" $(2014,25)$. And this "fundamental inequality" appears to be what most reviewers and commentators have taken from his work, leaving them with the impression that distribution is the consequence of an economic logic.

It has not only been mainstream economists who have generally given little or no role to politics in the determination of inequality. Their view can be found among many social thinkers. This is hardly surprising. As Robert Wade puts it, "economist, who constitute the most influential profession in shaping norms of public policy, are trained to presume that inequality is an inevitable outcome of the market as a coordinating mechanism, and a necessary outcome for the market to function as an incentive mechanism" $(2014,118)$. Thus, for instance, political historian Jerry Muller claims that the most recent surge in inequality "is not the result of politics, nor is politics likely to reverse it, for the problem is more deeply rooted and intractable than generally recognized. Inequality is an inevitable product of capitalist activity..." (2013).

Similarly, sociologist Peter Berger claims that "Income distribution is a function of modern economic growth and is affected to only a limited degree by the institutional arrangements and policies of a society" (1986, 219).

It is noteworthy that when economists and historians examine pre-capitalist societies, the fact that those who labor must give up their surplus to a ruling elite is generally understood in political terms and thus extreme inequality in those societies is taken to be politically based. Slavery is due to the political power of slave-owners, feudalism to the political power of landlords. However, when scholars examine the same phenomenon within capitalism, they most frequently ground the inequality in economic forces. This tendency flows out of a proclivity to see capitalism as a self-directing economic system wherein the political domain principally serves the function of the constable maintaining security and enforcing the laws. Little or no notice is taken of the fact that because these laws have been formulated principally in the interests of the owners of the means of production, inequality is the result.

In a parallel manner, Karl Marx criticized Classical economists for viewing all precapitalist societies as artificial, as human constructs, whereas they viewed capitalism as natural. He wrote of the "singular manner" in which for Classical economists there were "only two kinds of institutions, those of art and those of nature. Feudal institutions are artificial institutions, those of the bourgeoisie are natural institutions. In this they resemble the theologians, who also establish two kinds of religion. Every religion but their own is an invention of men, while their own religion is an emanation from God. In saying that existing economic conditions -- the conditions of bourgeois production -- are natural, the economists give it to be understood that these are the relations in which wealth is created and the productive forces developed conformably to the laws of nature.... They are eternal laws which must always govern society. Thus there has been history, but there is no longer any" $(1847,147)$.

But well before Marx, Adam Smith, the presumed father of modern economics, recognized that property rights, pace natural law ideology, are political creations. No property 
rights exist in nature, and without government's defense of property rights, only the most rudimentary inequality would be possible: "The acquisition of valuable and extensive property, therefore, necessarily requires the establishment of civil government. Where there is no property, or at least none that exceeds the value of two or three days labour, civil government is not so necessary" (1776, 670). Property rights, upon which inequality depends, are purely political creations. Property rights can only be defined and enforced by politically constituted government. Thus without the property rights of patent law, Bill Gates could not have become the wealthiest person on earth. Without politically protected trademarks, Sam Walton could not have built a commercial empire. Corporations are politically created to limit the personal responsibility of their owners who are overwhelming the wealthy. ${ }^{4}$

\section{The Political Character of Kuznets' Turning Point}

Because Kuznets' famous curve has defined a great deal of recent discourse concerning inequality, examining the nature of his curve's inflection point - where economic growth shifted fromceased increasing to decreasing -- is helpful for grasping the fact that inequality is ultimately politically generated.

Kuznets's claim that in the early stages of economic development inequality would increase conforms to the fact that workers lacked the vote and thus held little political power. They could and did at times revolt, but repressive responses were quick and often brutal. Consequently, worker wages could be held near bare subsistence such that any increases in productivity would necessarily increase inequality since most output above subsistence would accrue to the elite owners of the means of production.

Not only did industrialization and urbanization accompanying economic growth increase inequality, it also greatly augmented the potential, as Marx anticipated, that the working class could organize and threaten violence against the elites' state for redress. The evolution of an urban industrial working class brought with it organized, at times violent, resistance to long workdays, low wages, and unhealthy working conditions. To reduce and hopefully eliminate the threat of violence, elites began bribing the working class with various benefits and with the franchise. Both strategies for calming working class revolutionary fervor resulted in higher living standards for workers. Thus, the changes in inequality were being politically generated.

Although immediately costly to elites-lowering the amount of surplus they could appropriate - they realized that the alternative of violence and revolution promised to be far worse. ${ }^{5}$ They understood, as Muller and Seligson observe, that "the presence of meaningful nonviolent possibilities of influencing the political process will inhibit the ability of revolutionary-minded dissidents to mobilize large followings" $(1987,444)$. This possibility had been foreseen by De Tocqueville, who much earlier had noted how political inclusion of disgruntled groups served to quiet social resentment. He was well aware of how when conservative elites in France had vociferously opposed extending the franchise, devastating urban riots followed (1899).

\footnotetext{
${ }^{4}$ In 2007, the wealthiest one percent of Americans owned 49.3 percent of stocks and mutual funds, the richest 10 percent, 89.4 percent, leaving the bottom 90 percent with only 10.6 percent (Wolff 2010, Table 9: 52).

${ }^{5}$ Marx and Engels famously wrote, "The executive of the modern State is but a committee for managing the common affairs of the whole bourgeoisie" $(1848,475)$. But what they failed to adequately appreciate is that this committee would be savvy enough to do what was necessary to appease a revolutionary working class and thereby defuse their revolutionary proclivities.
} 
The following examples reveal the dynamics of the political response to the threat of worker insurrection and the resulting improvement in worker welfare. The initial extension of the franchise in Britain in 1832 followed, as Acemoglu and Robinson note, "unprecedented political unrest, including the Luddite Riots from 1811-1816, the Spa Fields Riots of 1816, the Peterloo Massacre in 1819, and the Swing Riots of 1832" (2000, 1182-83). To quell worker militancy, England introduced the 10-hour working day in 1847. Following the revolution of 1848 , "Britain... was transformed from an 'oligarchy' run by an elite to a democracy" (Acemoglu and Robinson 2000, 1167). Further extension of the franchise in 1867 came with a heightened threat of violence due to a severe economic downturn. This was followed by lessened inequality and welfare measures paid for by the fact that "taxes as a proportion of National Product more than doubled in the 30 years following 1870, and then doubled again" (Acemoglu and Robinson 2000, 1191). These taxes fell most heavily upon the elites.

Although universal male suffrage had been introduced by the French Revolution, in subsequent decades it was whittled down until, following the 1830 revolution, the Orleanist monarchy used property restrictions to limit it to a mere 0.75 percent of the population. But the Revolution of 1848 was the big wakeup call for the elites. It became clear that political reforms with distributional consequences had to be made to avoid a revolution that would abolish their privileges. In the wake of the 1848 revolution and the collapse of the Orleanist monarchy in 1849 , male suffrage was again extended to all males. Continued concern about worker insurrection led France to create compulsory workmen's compensation insurance in 1898, requiring payment to injured workers regardless of fault. This represented socialization of the very idea of responsibility (Rosanvallon 2013, 195). The individual no longer stood alone, but was part of society that had obligations to its citizens.

The elite in Germany also began extending the franchise following the 1848 revolution. However, rather than further extending it several decades later in response to an increasingly threatening working class (organized under a socialist party), the elite chose instead to bribe them with extensive welfare measures. Germany's Social Democratic Party embraced a Marxist program in 1875 . To counter its rising political challenge, Otto von Bismarck set forth social measures between October 1878 and 1890 that served to defang the threat. Before the Reichstag, Bismarck argued that "If the wounds are to be healed, we must not only repress the excesses of social democracy but also, in a more positive sense, foster the well-being of workers" (cited in Rosanvallon 2013, 174).

Bismarck introduced compulsory health insurance in 1883, paid for by both employers and workers. The following year, worker accident insurance was introduced, and in 1889, oldage insurance and mandatory retirement. Again, it should be emphasized that changes in the distribution of society's income were being determined politically, and not by economic forces such as markets or technology.

Over the following decades, other European countries introduced many of the same measures. Much of what had earlier been viewed as the domain of charity was taken over by the state and came to be seen as rights. The state presented itself as an agent for social solidarity.

Although bought off, worker welfare greatly improved. Extension of the franchise in response to threats of violence and revolution from below led to labor reform, and especially to a democratization of education. In England, for instance, enrollment of 10-year-olds soared from 40 percent in 1870 to 100 percent in 1900 (Acemoglu and Robinson 2000, 1191). Through the political process, workers were gaining the right for their children to accumulate human capital, an increasingly important form of wealth. 
Even more striking was the dramatic improvement in health. Cleaner water and better nutrition as worker incomes rose enabled children to grow up taller, stronger, with longer life spans. Deaton describes the political dynamic as follows: "Whenever health depends on collective action - whether through public works, the provision of health care, or education politics must play a role. In this case, the (partial) removal of one inequality - that working people were not allowed to vote - helped remove another inequality - that working people had no access to clean drinking water" $(2013,98)$.

Thus, nineteenth century European history clearly reveals that the inflection point of the Kuznets curve - where economic growth switched from increasing to decreasing inequality -was fully political, following upon the reaction of the ruling elites to the threat of violence and revolution. Accordingly, Acemoglu and Robinson find that for the countries they examine (Britain, France, German, and Sweden) "inequality peaked approximately at the time of the major political reforms, and fell sharply after the extension of the franchise." Williamson's empirical work supports this timing, finding that rising inequality appears to have begun in England around 1760, peaking in the 1860s, after which inequality mildly decreased until World War One (1991: 15). This fall was politically driven "in large part due to major redistributive efforts including increased taxation, investment in education of the poor, and labor market reform" (Acemoglu and Robinson 2000, 1193; 1180).

Compared to the European experience, the U.S. was an anomaly, starting out far more egalitarian (Engerman and Sokoloff 1994). Notions of equity pervaded both the economic and governmental spheres in the United States, with titles of nobility specifically prohibited in its Constitution (Article I, Section 9). The Land Ordinance of 1785 and later The Homestead Act of 1862 that expanded opportunities for the lower classes are evidence of the greater degree of political power possessed by the general population. The lands might have been sold for a pittance to monied interests instead. Rosanvallon claims that "In America one can speak of a continuous revolution. The thirty years between the presidencies of George Washington and Andrew Jackson were notable for a steady rise of the egalitarian ethos. Federalist ideas gradually receded while 'republican' ideas gained strength" $(2013,61)$. Something like the agrarian democracy that developed in the U.S. during the Jacksonian period also come forth in Switzerland and Norway.

The progressively greater democratization at the ballot box decreased the ease with which elites could use the state to violently curb the aspirations of workers, especially in putting down strikes. Only control over ideology could promise retention of their control over the state. Always before, excepting severe crises, they had been successful in convincing the producers below that what was more narrowly in the interests of elites was equally in the interests of the workers. But now the elites faced a new challenge. They could no longer as easily back up their ideology with violence. The elites had lost their violence-backed monopoly control over the state.

The democratization of the franchise that came with the increasing threat of worker violence foiled the expectations of Marxists that workers would overthrow capitalism and institute socialism. But given Marx's understanding of ideology control, it is hardly surprising that the working class would not follow through: "The class which has the means of material production at its disposal, has control at the same time over the means of mental production, so that.. the ideas of those who lack the means of mental production are subject to it $(1845,172)$. Accordingly, the bourgeoisie had been able to take political power from the aristocracy because it came to control capital, the principal evolving means of production, along with an ideology 
legitimating this ownership. Nothing parallel to this occurs for the proletariat. They struggle for political power without command over the means of production and thus command over ideology. They have only their greater numbers.

Nevertheless, by the end of the nineteenth century and beginning of the twentieth, workers had used the state to politically advance their collective interests on an unprecedented scale. The state had been transformed from the executive committee of the ruling class to that social agency that could limit, or in the extreme eliminate the capturing by elites of disproportionate shares of income, wealth, and privilege. Without revolution, the working class had in principal gained power to rewrite the social script. That they did not fully do so is testament to the power elites retained over ideology.

\section{The Critical Role of Ideology}

Even when Kuznets' entreaty to broaden analysis to political and social factors has been heeded, the role of ideology has typically not received substantial attention. Yet throughout history, the elite's superior influence over the generation and character of ideology has played a usually decisive role in the maintenance of their ability to appropriate most of society's surplus. Ideology has always been the most powerful political weapon.

Ideology is deception, although not usually conscious deception. It's a form of mystification that serves specific interests. It promotes a mistaken view of aspects of reality, most importantly, social aspects and social relations. In doing so, it has always been a powerful instrument for creating and maintaining inequality. ${ }^{6}$

Ideology is an aspect of legitimation. Legitimation is used here to indicate a set of beliefs concerning the nature of reality. It concerns how people mentally experience and understand their world. As such, it is neither positive nor negative. Humans evolved such that they must give meaning to their world (Berger 1990). Ideology, by contrast, refers to the way in which reality is mystified so as to serve special interest. It presents a false view of social relations and thus enables the exploitation of some by others.

Humans have produced three broad, highly interrelated categories of tools to control their world. A highly simplified way of putting this is that technology promises more efficient control of the physical world; social institutions promise more efficient control of social processes, and legitimation permits control of the mental world. Ideology is a subdomain of legitimation. These three broad categories overlap and are highly interrelated in their functioning. Technology influences social processes and mental acts. Institutions can control physical processes and mental acts. And legitimation affects and controls all humans do.

At times, economic, demographic, ecological, or natural events brought on crises severe enough to threaten the elite's ideology and thus their fitness to rule. However, their superior command over ideology always permitted them to eventually reclaim legitimacy and society's surplus.

Inequality can be maintained by either physical or ideological force. Physical force has often been necessary for initially establishing and solidifying a hierarchical social structure. However, brute force is relatively inefficient in that it generates strong resentment and the constant threat of insurrection. It is also costly in terms of policing resources. A far more efficient and effective long-run strategy - one that decreases the costs of physical repression and terror -- is for the elites to generate an ideological system that convinces not only themselves but all beneath them of the moral and functional appropriateness of the existing social order. Those

\footnotetext{
${ }^{6}$ For an extensive treatment of the manner in which inequality has been legitimated throughout human history, see Wisman and Smith 2011.
} 
below are led to believe that their lesser status in terms of income, wealth, and privilege is as it must be.

With the exception of periods of extreme crises, inequality has always been adequately legitimated such that most folks found it acceptable, even when it meant their lives were filled with extreme hardship and misery. This was especially true if all other sufferers remained quiescent. As Tolstoy famously noted, there are "no conditions of life to which a man cannot get accustomed, especially if he sees them accepted by everyone around him" (2000).

\section{Religious Legitimation}

In pre-modern traditional societies, religion served as the predominant, if not nearly exclusive means of legitimation. Religion provides a status to prevailing social institutions that transcends their human genesis. As Peter Berger has expressed this, "Religion legitimates social institutions by bestowing upon them an ultimately valid ontological status, that is, by locating them within a sacred and cosmic frame of reference" (1990, 33). In this manner, social institutions are accorded the stability and inevitability that is ascribed to the ultimate spiritual and material realms. Religious legitimation of social institutions provides individuals with enormous solace by providing them with an ultimate sense of rightness. It is in this manner that inequality was provided with legitimacy. It was the will of gods, or the cosmically mandated, and therefore the way it must be. As Berger puts it, "One of the very important social functions of theodicies is, indeed, their explanation of the socially prevailing inequalities of power and privilege.... theodicies provide the poor with a meaning for their poverty, but may also provide the rich with a meaning for their wealth" $(1990,59)$.

\section{"Economic Science": Born and Nurtured as Ideology}

With the rise of capitalism and secular society generally, religious legitimation weakened and inequality came to be increasingly legitimated in secular, and especially economic terms. Secular economic thought began advancing during the Mercantilist period of early capitalism and became increasingly dominant as its coverage and coherence increased during the period of classical economics. Yet, as A.M.C. Waterman points out, it was not until the 1880 s that "It was no longer part of the professional duty of economists to reconcile their findings with Christian theology" $(2008,136)$. Economics, wearing the mantle of science, gradually evolved to serve as the dominant ideological instrument for legitimating inequality, a role it continues to perform today.

Five distinct inequality-legitimating doctrines came forth during Mercantilism (circa 1500-1750) and the subsequent era of classical political economy. They were: the utility of poverty, the justice of the invisible hand, the Malthusian population doctrine, the wages-fund doctrine, and the trickle-down thesis.

The utility of poverty doctrine suggested that should wages rise above mere subsistence, workers would work less, thereby decreasing society's output and weakening the state at a time when state competition in Europe was especially belligerent. ${ }^{7}$ It legitimated state-enforced maximum wages capping what employers could legally pay, thereby ensuring that the working class remain in relative poverty. To appease social conscience as to the workers' welfare, it was argued that having either greater free time or more income would result in debauchery or sinful

\footnotetext{
7 The utility of poverty argument would later be expressed in the backward-bending supply curve of labor. For an extended discussion, see (Wisman 1989).
} 
behavior on the part of workers. ${ }^{8}$ Low wages and poverty were thus in everyone's interest, hence the "utility of poverty."

The invisible hand doctrine claimed that if markets were left alone - laissez-faire - to operate according to natural laws, then resources would be allocated efficiently. The distribution of income, wealth, and privilege that flowed from market processes was natural, and therefore just, the moral being equated with what was presumed natural. No assistance need or should be offered to the poor, lest the efficient operation of natural markets be impaired.

The Malthusian population doctrine held that because humans, and especially poor ones, are ruled by their passions, population growth will outpace the growth of food output. If workers were to receive higher wages, they would parent more children, eventually increasing the supply of labor and thereby pushing wages back down to subsistence - the iron-law of wages. In addition, since food output would not keep up with demand of a growing population, distress was inevitable. The poor -- the far greater part of humanity -- are condemned by the laws of nature to live at the edge of starvation, and in fact, often starve: "It has appeared, that from the inevitable laws of our nature some human beings must suffer from want. Those are the unhappy persons who, in the great lottery of life, have drawn a blank" (Malthus 1960, 74), and "No possible sacrifices of the rich, particularly in money, could for any time prevent the recurrence of distress among the lower members of society, whoever they were" (Malthus 1960, 31).

The wages-fund doctrine contended that a "wages fund" was made up of previously produced items that labor consumes, principally such goods as food, housing, and clothing. This fund was fixed by output in the previous period, thus carrying the implication that any attempt to raise general wages would be futile. The wages fund doctrine meant that combinations of workers (labor unions) could not increase the welfare of the working class, since if they were successful at raising their members' wages, it would be at the expense of non-organized workers.

The trickle-down thesis saw economic dynamism resulting from saving and investment carried out uniquely by the rich. If there were greater equality, less would be saved and invested, impairing economic growth. Because everyone is presumed to benefit from a dynamic, growing economy, inequality benefits even the poor -- the benefits trickle down to everyone, or in another common metaphor, a rising tide lifts all boats.

Although the wages-fund doctrine was abandoned toward the end of the nineteenth century, the other four inequality-legitimating doctrines, with varying frequency and intensity, have continued to serve as ideology for maintaining, if not augmenting, inequality in the distribution of income, wealth, and privilege.

\section{A More "Scientific" Science of Economics}

In the last three decades of the nineteenth century, the mainstream of economics got redefined in an attempt to make it more scientific. This involved emphasizing marginal change, permitting its theoretical expression to draw upon calculus, and as George Stigler famously put it, economics was transformed "from an art, in many respects literary, to a science of growing rigor" $(1941,1)$.

This remake also involved an attempt to sever economic science from its earlier "Classical" orientation that understood economic phenomena in terms of social classes and

\footnotetext{
${ }^{8}$ Malthus wrote that "even when they have an opportunity of saving they seldom exercise it, but all that is beyond their present necessities goes, generally speaking, to the ale-house" (Malthus 1960, 34).
} 
political power, often drawing substantially on history and institutional structure to clarify the complex relationships economics examined. This older approach had been called political economy. The new brand dropped the political and became simply economics or, as its proponents imagined, economic science. Its dependence on marginalism also narrowed its focus to principally market phenomena which could be fairly well modelled using calculus, thus giving it the patina of a science like physics. Contemporary mainstream economics is constructed upon the fundamental orientation set forth during this "neoclassical revolution." Indeed, it is often still referenced as neoclassical economics.

Presumably, this more scientific economics would be free, or at least freer of ideology. However, the new economics was every bit as ideological as the old. It legitimated inequality with equal if not greater adroitness, thanks to its presumed heightened status as "science," and its far more formalistic mode of expression, which not only made it appear more like physics, but also made it opaque to non-economists.

Marginal analysis made it possible to construct a theoretical model in which it was possible to see the contribution of each additional unit of a factor of production - typically understood as land, labor and capital - to the value of the final product. In his highly influential The Distribution of Wealth, John Bates Clark asserted "It is the purpose of this work to show that the distribution of income of society is controlled by a natural law, and that this law, if it worked without friction, would give to every agent of production the amount of wealth which that agent creates." (1908, v).

Within this theoretical framework, all get what they deserve, the just return for what they contribute to the value of economic output, an idea that was already implicit in the natural law cosmology of the "invisible hand." What neoclassical analysis added was analytical rigor to make the case quite explicit and theoretically clear. Free market capitalism is just. Further, because all get their just desserts, free markets are understood as providing the incentive structure for a robust and dynamic economy. Ignored is the manner in which political power creates, defines, and enforces property rights that underlie what individuals bring to markets.

By recognizing social classes, social and by extension political power played critical roles in Classical political economy. By contrast, social and political power were exiled from neoclassical economics. They concerned issues outside of the scope of the new more scientific economics. Indeed, from within this analysis, they would not likely ever come to mind. As Abba Lerner put it, "Economics has gained the title of Queen of the Social Sciences by choosing solved political problems as its domain" (1972, 259).

Fully lost, then, was any perspective that might resemble that of Marx. For Marx, the fundamental character of capitalism was located in its specific form of inequality, whereby an elite owned and controlled capital (stored up labor) and natural resources, forcing workers to contract with them to be able to work and survive. For this right to work, workers had to pay the high price of their surplus labor, the value of what they produced in excess of what was needed for their subsistence needs. Whereas from the neoclassical perspective, capitalists paid workers, from Marx's perspective, workers paid capitalists with their surplus for the right to work and therefore survive. Further, ownership of the means of production provided the elite with control over ideology and thus political power.

The inequality-justifying character of neoclassical economics finds support, especially in the U.S., from three complementary contemporary currents of thought: libertarianism, the belief in fluid vertical mobility, and the view of government as incompetent. Neoclassical economics and libertarianism share common intellectual roots in the Western Enlightenment tradition that 
sets the autonomous individual at the center of the social world. ${ }^{9}$ Its ethical foundation is the single, broadly-conceived, and inviolable right of self-ownership. This means that individuals have a right to dispose of their persons and legitimately-acquired property as they choose. Therefore, libertarianism proscribes outside interference with the right of individuals to do as they please with themselves or their property. Justice never permits the state to take legitimatelyacquired property from some individuals in order to give to others, no matter how great the benefits to recipients, relative to the costs to donors. All such transfers would involve confiscation or coercive taxation and thus constitute an unacceptable infringement of the right to self-ownership.

Neoclassical economics' claim that all economic actors get their just desserts reinforces the view that by dint of hard work, anyone can make it to the top. This idea of fluid vertical mobility has deep roots in U.S. culture. For much of its history, thanks to abundant land and emigrants who fled Europe's rigid class structure, there was greater social mobility in America than anywhere else on Earth. Consequently, Americans more readily take credit for their successes and find the poor responsible for their poverty. ${ }^{10}$ Accordingly, many contemporary social thinkers and economists, like their nineteenth century classical predecessors, lodge the source of inequality in the virtues of the rich and the personal failings of the less well-off. ${ }^{11}$ For them, inequality is not viewed as a major problem since unequal outcomes are testimony to the successes of competitive markets. Freedom of choice means responsibility for these choices.

President Reagan's identification of government as the problem has become ever more widely embraced (Wisman 2013). Pharr and Putnam have found support for the claim that people in rich countries have become more convinced that their governments are untrustworthy: "The onset and depth of this disillusionment vary from country to country, but the downtrend is longest and clearest in the United States where polling has produced the most abundant and systematic evidence" $(2000,8)$. Whereas in the mid-1950s, three-quarters of Americans agreed with the statement "You can trust the government to do the right thing most of the time," only 10 percent currently agree (R. Wade 2012, 33). This hostility towards government has legitimated cuts in welfare and public goods that benefit the less well off, thus enabling more income, wealth, and privilege to be captured by elites.

The grand contours of the manner in which ideology influences politics, which in turn sets the rules of the game for distribution, can be vividly seen in the U.S. experience since the 1930s. The next section turns to that story.

\section{From the "Great Compression" to the Great Reversal in the U.S.}

\footnotetext{
${ }^{9}$ Many of the most distinguished intellectual defenders of inequality -- such as the late Milton Friedman and his colleagues from the Chicago School -- view the social scientific and libertarian arguments as complementary, and freely mix them in their writings for general audiences.

${ }^{10}$ However, over the past few decades, multiple studies have found that there is less vertical mobility in the U.S. than in other rich societies such as Canada, Sweden, Germany, Spain, Denmark, Austria, Norway, Finland, and France (Jäntti et al. 2006; ; Hertz 2007; Mishel, Bernstein, and Allegretto 2007; Mazumder 2005; Bowles and Gintis 2002; Solon 1992).

${ }^{11}$ Ron Haskins, for instance, claims that “...opportunity in America depends largely on decisions made by people who are free actors....Unless young Americans begin making better decisions, the nation's problems with poverty and inequality will continue to grow.... Yes, the nation needs its safety net, but improvements in personal responsibility would have a greater and more lasting impact on poverty and opportunity" (2012, A15).
} 
The Great Depression's widespread suffering called laissez-faire political and economic policies into question. It also challenged the prevailing economic theory that legitimated these policies, making space for the Keynesian revolution. This delegitimation of the elite's ideology, their most powerful political tool, led to political changes during the subsequent four decades that reduced inequality in income, wealth, and opportunity. These political changes were guided and made possible by economic doctrines that depicted greater equality as positive and active government intervention as essential for a prosperous and fair economy. Only government could guarantee a "New Deal."

The most outstanding government measures reducing inequality and improving conditions for the broad population included workers' rights to collectively bargain, minimum wages, Social Security, the G.I. Bill, Medicare, Medicaid, Food Stamps, public housing and rent subsidies, Project Headstart, Job Corps, Occupational Safety and Health Administration, the Consumer Product Safety Commission, the Mine Enforcement and Safety Administration, and the Environmental Protection Agency. Public goods that benefit the general population such as schools, community colleges and state universities, parks, playgrounds, and public transit were vastly expanded in quantity and quality. Highly progressive income taxation also reveals the intent of redistribution toward greater equality. The highest marginal income tax rates were: 1942-43: 88 percent; 1944-45: 94 percent, 1946-50: 91 percent. Top marginal tax rates remained in the upper 80s percent from 1951 until 1964, and 70 percent from 1965 until 1981. ${ }^{12}$

Whereas the top one percent of households in 1929 received 22.5 percent of all pre-tax income (including capital gains), they received only nine percent by the late 1970s (Piketty and Saez 2006). What Burns termed a "revolutionary leveling" (in Williamson1991: 11), and Goldin and Margo, the "Great Compression" (1992)(1992) between the 1930s and mid-1970s, seemed to confirm Kuznets' conjecture that inequality would decrease in the later stages of economic development. Thanks to the relative delegitimation of the elites' ideology and thus political power, relative wealth distribution returned to a state that had disappeared in the decades after the Civil War.

However, by the mid-1970s, ideology began turning against the active government intervention that had benefited the broad population for four decades. Due to the elites' wealth, superior education, and influence over the political sphere, this ideological reversal was destined to happen eventually. The specific events that facilitated this reversal are addressed below.

Stagflation had delegitimated Keynesian economics, ${ }^{13}$ setting the stage for a strong rejection of government intervention in the economy. Liberal policies were alleged to be at the root of what pundits claimed was the decline of the American century. Evidence included loss of

\footnotetext{
${ }^{12}$ The impact of tax rates on inequality is clear. OECD countries in which taxes have been cut most on high incomes have witnessed the greatest increases in income accruing to the very wealthy (Deaton 2013, 212). Piketty also notes that "...the resurgence of inequality after 1980 is due largely to the political shifts of the past several decades, especially in regard to taxation and finance" (Piketty 2014, 20).

${ }^{13}$ As Chicago School economist John Cochrane has put it, "When inflation came in the nineteen-seventies, that was a major failure of Keynesian economics" (cited in Cassidy 2010, 31). As early as 1980, Robert Lucas wrote that "At research seminars, people don't take Keynesian theorizing seriously anymore; the audience starts to whisper and giggle to one another" $(1980,19)$.
} 
gold backing of the dollar and its devaluation, loss of the Vietnam War, and with the widespread use of recreational drugs and sexual promiscuity, alleged rising moral degeneracy. ${ }^{14}$ Welfare, union power, and labor legislation were claimed to have sapped work incentives. High taxes, especially on the rich, allegedly reduced entrepreneurial energies and the incentives to save and invest, resulting in stagnation and anemic tax revenues (the infamous "Laffer Curve").

Legislation flowing out of the rising discontent with liberalism reversed the trend toward greater equality. This shift of income toward the rich set in motion a self-reinforcing process since it meant that they commanded yet more resources with which to influence public opinion and policy. And research reveals that their expenditures on creating and disseminating ideology yield high returns (Glaeser and Saks 2006). The consequence is that inequality today has reached levels of the 1920s. The elite, thanks to their recapture of ideology that guided political policy to change the economic rules of the game, recaptured all that they had lost during the four decades of the "great compression" and then some (Wisman and Pacitti 2015).

\section{Final Reflections}

The general strategy followed in this article for demonstrating that distribution is ultimately determined politically has been an examination of the forces behind two modern historical periods that witnessed substantial changes in distribution of income, wealth, and privilege. The political struggles by the working class forcing an inflection in the Kuznets' curve provide a rich story of the manner that distribution is determined ultimately by politics. The distribution history of the U. S. since the Great Depression reveals the critical importance of ideology in guiding politics.

Yet in spite of the historical evidence, inequality continues to be generally depicted by the economics profession, as well as many other social scientists and political commentators, as the consequence of economic forces. While this is not false, it is deceptively incomplete. All economic processes occur within an institutional context that captures the politically-created rules of the game. Further, any distributional changes brought about by such economic forces as technological change or globalization can be politically reversed or neutralized through government taxation, spending, and regulation. Ultimately, the degree of inequality in any society is politically determined.

The depiction of inequality as generated by economic forces serves as an ideology suggesting that it is the natural outcome of growth-promoting economic processes. This ideology impedes political intervention to achieve desired distributional goals. It is especially at work where prevailing economic institutions or rules of the game are depicted as the essential ones for economic dynamism, which is further presumed to "raise all boats" such that even if inequality is increasing, those at the bottom are absolutely (materially) better off - the classic trickle down thesis. However, a number of studies challenge the claim of a positive relationship between inequality and economic dynamism, finding instead that greater income inequality causes economies to grow more slowly (Alesina and Rodrik 1994; (Bernstein 2013; Easterly 2002; Persson and Tabellini 1994). The deputy director of the IMF's highly reputable research

\footnotetext{
${ }^{14}$ Home-grown domestic terrorism also characterized this period. In 1972, there were nineteen hundred domestic bombings. Terrorist groups included the Weathermen, the Black Liberation Army, and the Symbionese Liberation Army (Burrough 2015).
} 
department, Jonathan Ostry, claims that "On average, redistribution seems to have helped support faster and more durable growth"(in (Talley 2014)). He elaborates that excessive inequality harms growth by reducing access to health and education and by increasing political instability.

Yet these findings are generally ignored by most economists and consequently most policy makers. They continue to essentially embrace the ideology of the doctrine of trickle down.

Ideology has always been the most powerful political weapon and it has almost always been controlled by elites who possess all the privileges that enable this control. They receive the best educations, they possess the most gifted friends, and they can afford the most talented creators of ideology (think tanks, media ownership, university research grants and chairs).

Command of ideology is, of course, relative. But in the grand course of human history, only rarely has the elite's command weakened to the point where workers were left with significantly more than mere subsistence, and in only one instance - the 1930s to the 1970s - did their command weaken to the point that inequality actually decreased. This historical backdrop of only one instance reveals the magnitude of the challenge for those who believe that lessened inequality is essential for a better social future.

\section{References}

Acemoglu, Daron, and James A. Robinson. 2000. "Why Did the West Extend the Franchise? Democracy, Inequality, and Growth in Historical Perspective." The Quarterly Journal of Economics 115 (4): 1167-99. doi:10.1162/003355300555042.

- 2012. Why Nations Fail: The Origins of Power, Prosperity and Poverty. 1st ed. New York: Crown Publishers.

Aghion, Philippe, and Patrick Bolton. 1997. "A Theory of Trickle-Down Growth and Development." The Review of Economic Studies 64 (2): 151-72. doi:10.2307/2971707.

Alesina, Alberto, and Dani Rodrik. 1994. "Distributive Politics and Economic Growth." The Quarterly Journal of Economics 109 (2): 465-90. doi:10.2307/2118470.

Berger, Peter L. 1986. The Capitalist Revolution: Fifty Propositions about Prosperity, Equality, and Liberty. New York: Basic Books. 1990. The Sacred Canopy: Elements of a Sociological Theory of Religion. New York: Anchor.

Bernstein, Jared. 2013. "The Impact of Inequality on Growth.” Name. http://www.americanprogress.org/issues/economy/report/2013/12/04/72062/the-impactof-inequality-on-growth/.

Bowles, Samuel, and Herbert Gintis. 2002. "The Inheritance of Inequality." Journal of Economic Perspectives 16 (3): 3-30. doi:10.1257/089533002760278686.

Burrough, Bryan. 2015. Days of Rage: America's Radical Underground, the FBI, and the Forgotten Age of Revolutionary Violence. New York: Penguin Press.

Cassidy, John. 2010. "After the Blowup." The New Yorker, January 11. http://www.newyorker.com/reporting/2010/01/11/100111fa_fact_cassidy.

Clark, John Bates. 1908. The Distribution of Wealth. New York: Augustus M. Kelley.

Deaton, Angus. 2013. The Great Escape: Health, Wealth, and the Origins of Inequality. Princeton, N.J: Princeton University Press.

Easterly, William. 2002. The Elusive Quest for Growth: Economists' Adventures and Misadventures in the Tropics. Cambridge: MIT Press.

Engerman, Stanley L., and Kenneth L. Sokoloff. 1994. "Factor Endowments: Institutions, and Differential Paths of Growth Among New World Economies: A View from Economic 
Historians of the United States.” Working Paper 66. National Bureau of Economic Research. http://www.nber.org/papers/h0066.

Glaeser, Edward L., and Raven E. Saks. 2006. "Corruption in America." Journal of Public Economics 90 (6-7): 1053-72. doi:10.1016/j.jpubeco.2005.08.007.

Goldin, Claudia, and Robert A. Margo. 1992. "The Great Compression: The Wage Structure in the United States at Mid-Century.” The Quarterly Journal of Economics 107 (1): 1-34. doi: $10.2307 / 2118322$.

Haskins, Ron. 2012. "Decisions That Doom the Future.” The Washington Post, March 30: A15. Hertz, Tom. 2007. "Trends in the Intergenerational Elasticity of Family Income in the United States." Industrial Relations 46 (1): 22-50. doi:10.1111/j.1468-232X.2007.00456.x.

Jäntti, Markus, Bernt Bratsberg, Knut Røed, Oddbjørn Raaum, Robin Naylor, Eva Österbacka, Anders Björklund, and Tor Eriksson. 2006. "American Exceptionalism in a New Light: A Comparison of Intergenerational Earnings Mobility in the Nordic Countries, the United Kingdom and the United States.” Working Paper 1938. IZA Discussion Paper. Bonn, Germany: Institute for the Study of Labor (IZA). http://ideas.repec.org/p/iza/izadps/dp1938.html.

Kuznets, Simon. 1955. "Economic Growth and Income Inequality." American Economic Review 45 (1): 1-28.

. 1995. "Economic Growth and Income Inequality." American Economic Review 45 (1): $1-28$.

Lantican, Clarita P., Christina H. Gladwin, and James L. Seale. 1996. "Income and Gender Inequalities in Asia: Testing Alternative Theories of Development." Economic Development and Cultural Change 44 (2): 235-63.

Lerner, Abba. 1972. "The Economics and Politics of Consumer Sovereignty." American Economic Review 62: 258-66.

Lindert, Peter H. 1986. "Unequal English Wealth since 1670.” Journal of Political Economy 94 (6): 1127-62. doi:10.1086/261427.

Lucas, Robert E. 1980. "The Death of Keynesian Economics." Issues and Ideas, 18-19.

Malthus, Thomas Robert. 1960. On Population. Edited by Gertrude Himmelfarb. 1st ed. New York: Random House.

Marx, Karl. 1845. "The German Ideology." In The Marx-Engels Reader, edited by Robert C. Tucker, 2nd ed., 146-202. New York: Norton \& Co. . 1847. "The Poverty of Philosophy." http://www.marxists.org/archive/marx/works/subject/hist-mat/pov-phil/ch02.htm.

Marx, Karl, and Friedrich Engels. 1848. "Manifesto of the Communist Party." In The MarxEngels Reader, edited by Robert C. Tucker, 2nd ed., 469-500. New York: Norton \& Co.

Mazumder, Bhashkar. 2005. "Fortunate Sons: New Estimates of Intergenerational Mobility in the United States Using Social Security Earnings Data." Review of Economics and Statistics 87 (2): 235-55. doi:10.1162/0034653053970249.

Mishel, Lawrence, Jared Bernstein, and Sylvia Allegretto. 2007. The State of Working America. Ithaca, NY: Cornell University Press.

Moran, Timothy Patrick. 2005. “Kuznets's Inverted U-Curve Hypothesis: The Rise, Demise, and Continued Relevance of a Socioeconomic Law.” Sociological Forum 20 (2): 209-44. doi:10.1007/s11206-005-4098-y.

Muller, Edward N., and Mitchell A. Seligman. 1987. "Inequality and Insurgency." The American Political Science Review 81 (2): 425-52. 
Muller, Jerry Z. 2013. "Capitalism and Inequality.” Foreign Affairs, April. http://www.foreignaffairs.com/articles/138844/jerry-z-muller/capitalism-and-inequality.

Persson, Torsten, and Guido Tabellini. 1994. "'Is Inequality Harmful for Growth? Theory and Evidence,."” American Economic Review 84: 600-621.

Pharr, Susan J., and Robert D. Putnam. 2000. Disaffected Democracies: What's Troubling the Trilateral Countries? Princeton, N.J: Princeton University Press.

Piketty, Thomas. 2014. Capital in the Twenty-First Century. Harvard University Press.

Piketty, Thomas, and Emmanuel Saez. 2006. "The Evolution of Top Incomes: A Historical and International Perspective.” Working Paper 11955. National Bureau of Economic Research. http://www.nber.org/papers/w11955.

Robinson, Joan. 1981. What Are the Questions? And Other Essays. M.E. Sharpe.

Rosanvallon, Pierre. 2013. The Society of Equals. Cambridge, Mass: Harvard University Press.

Smith, Adam. 1776. An Enquiry into the Nature and Causes of the Wealth of Nations. New York: The Modern Library.

Solon, Gary. 1992. "Intergenerational Income Mobility in the United States." American Economic Review 82 (3): 393-408.

Srinivasan, T. N. 1977. "Development, Poverty, and Basic Human Needs: Some Issues." Food Research Institute Studies, no. 02. http://ideas.repec.org/a/ags/frisst/135545.html.

Stigler, George J. 1941. Production and Distribution Theories. New York: Macmillan.

Stiglitz, Joseph E. 2012. The Price of Inequality: [How Today's Divided Society Endangers Our Future]. 1st ed. New York: W.W. Norton \& Co.

Talley, Ian. 2014. "Redistributing Wealth to the Poor Doesn't Burden Growth, IMF Note Says." WSJ Blogs - Real Time Economics. February 26.

http://blogs.wsj.com/economics/2014/02/26/redistributing-wealth-to-the-poor-doesntburden-growth-imf-note-says/.

Tinbergen, Jan. 1974. "Substitution of Graduate by Other Labor." Kyklos 27 (2): 217-26.

Tocqueville, Alexis de, and Henry Reeve. 1899. Democracy in America. New York: Vintage.

Wade, Robert. 2012. "Why Has Income Inequality Remained on the Sidelines of Public Policy for So Long?" Challenge 53 (3): 21-50.

Wade, Robert Hunter. 2014. "The Strange Neglect of Income Inequality in Economics and Public Policy." In Toward Human Development: New Approaches to Macroeconomics and Inequality, edited by Edward Giovanni, Andrea Cornia, and Francis Steward, 99121. Oxford: Oxford University Press.

Waterman, A. M. C. 2008. "The Changing Theological Context of Economic Analysis since the Eighteenth Century." History of Political Economy 40 (5): 121-42. doi:10.1215/00182702-2007-063.

Williamson, Jeffrey G. 1991. Inequality, Poverty, and History: The Kuznets Memorial Lectures. Cambridge, Mass., USA: Blackwell.

- 2005. Did British Capitalism Breed Inequality? London: Routledge.

Wisman, Jon D. 1989. "Straightening Out the Backward-Bending Supply Curve of Labor: From Overt to Covert Compulsion and Beyond." Review of Political Economy 1 (1): 94-112. . 2013. “Government Is Whose Problem?” Journal of Economic Issues 47 (4): 911-38. doi:10.2753/JEI0021-3624470406.

Wisman, Jon D., and Aaron Pacitti. 2015. "What the American Elite Won Over the Past 35 Years and What All Other Americans Lost." Challenge 58 (3): 1-25. 
Wisman, Jon D., and James F. Smith. 2011. "Legitimating Inequality: Fooling Most of the People All of the Time." American Journal of Economics and Sociology 70 (4): 9741013.

Wolff, Edward N. 2010. "Recent Trends in Household Wealth in the United States: Rising Debt and the Middle-Class Squeeze - An Update to 2007." SSRN Scholarly Paper ID 1585409. Rochester, NY: Social Science Research Network. http://papers.ssrn.com/abstract=1585409. 